\title{
Mapping the distribution of scale-rayed wrasse Acantholabrus palloni in Swedish Skagerrak using angling records
}

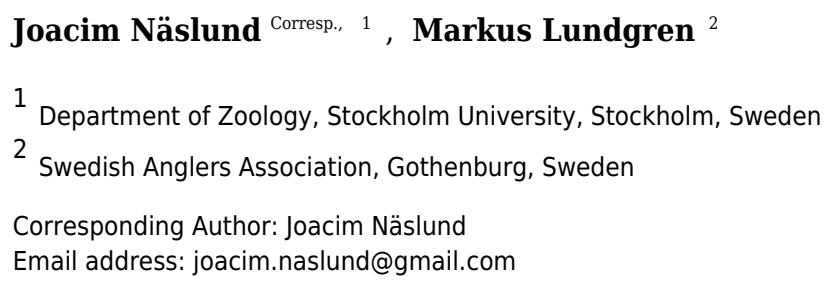

In this paper, we map the distribution of scale-rayed wrasse Acantholabrus palloni in eastern Skagerrak based on a combination of verified and personally communicated angling records. A recent surge in verified angling records in the Swedish Anglers Association's specimen database Storfiskregistret provides information to suggest that this species should no longer be considered an occasional guest, but rather a species established in the Swedish parts of Skagerrak. These records are supported by additional personal communications with anglers. The species is currently well spread geographically along the Swedish Skagerrak coast, with many locations providing repeated captures of adult fish over multiple years. The typical Swedish catch sites are rocky reefs located between the general 40-m and 80-m depth curves, likely influenced by currents bringing higher-salinity water from the North Sea. The present study show that angling records can provide an important, but underutilized, resource for mapping the distribution of datadeficient fish species. 


\section{records}


13 ABSTRACT

14

15 In this paper, we map the distribution of scale-rayed wrasse Acantholabrus palloni in eastern

16 Skagerrak based on a combination of verified and personally communicated angling records. A

17 recent surge in verified angling records in the Swedish Anglers Association's specimen database

18 Storfiskregistret provides information to suggest that this species should no longer be considered an occasional guest, but rather a species established in the Swedish parts of Skagerrak. These

20 records are supported by additional personal communications with anglers. The species is currently well spread geographically along the Swedish Skagerrak coast, with many locations providing

22 repeated captures of adult fish over multiple years. The typical Swedish catch sites are rocky reefs

23 located between the general 40-m and 80-m depth curves, likely influenced by currents bringing

24 higher-salinity water from the North Sea. The present study show that angling records can provide

25 an important, but underutilized, resource for mapping the distribution of data-deficient fish species. 


\section{BACKGROUND}

Records of rare species and their natural history can constitute important information for future research on these species and the ecosystems they occur in, e.g. with respect to human impacts (Boero 2013; Able 2016). Obtaining records of rare species is, however, time consuming and professional biologists are often active within projects limited in time and space, making alternative sources for information important (Devictor, Whittaker \& Beltrame 2010; Bradter et al. 2018). This is particularly true for records from aquatic environments, where the occurring species rarely can be observed directly, but rather have to be obtained by indiscriminate techniques such as trawls, nets, and dredges, which are also limited in their areal coverage at any given point in time. To achieve a larger spatial and temporal coverage, there is typically need for larger efforts and manpower than normally possible within a normal research project. Non-professional experts can help in the collection of species occurrence data, a feature which has been widely utilized for a long time within the scientific field of ornithology (Silvertown 2009; Dickinson, Zuckerberg \& Bonter 2010; Bradter et al. 2018). However, non-biologists well versed in species determination, -ecology and -distributions, exist not only for birds, but also for fish in the form of leisure anglers (e.g. Granek et al. 2008). Angling is a common leisure activity in large parts of the world (Arlinghaus, Tillner \& Bork 2015; Hyder et al. 2018) and anglers often document (photographs and personal journals; e.g. Banha, Ilhéu \& Anastácio 2015; Skov, Jansen \& Arlinghaus 2017) and report their catches (public or closed databases; e.g. Venturelli, Hyder \& Skov 2017; this paper: Materials and Methods). Some anglers are also specializing in 'collecting' different species [a similar concept to 'twitching' in the bird-watching community; see e.g. the Swedish online angling community '50-klubben' ('The club of 50 species'), http://www.50klubben.se/]. Information about rare species' occurrence is also commonly spread openly within the angler community (Lundgren 
50 \& Waje 2015) Hence, anglers' records and notes are excellent sources for confirmed qualitative 51 data on presence of species in certain areas and can be useful and important, but underutilized,

52 auxiliary and corroborating sources for mapping distributions and habitats of data-deficient species (e.g. Fetterplace et al. 2018). In this paper, the aim is to present a desktop study where citizengenerated data, in the form of private and publicly available angling records, are used to map out a tentative distribution map for a data-deficient species, the scale-rayed wrasse Acantholabrus palloni (Risso, 1810), in Swedish waters.

Acantholabrus palloni is a labrid fish inhabiting the eastern Atlantic Ocean and the Mediterranean Sea, with a known latitudinal range from Gabon in western Africa to mid- Norway, including areas around some of the eastern Atlantic offshore islands, like Madeira and the Canary Islands (Andersson 1942; Debelius, 1997; Muus, Nielsen \& Svedberg, 1999; Pollard, 2010; Kullander et al. 2012). The full range of the species is continuously being mapped out, with relatively recent documented records from e.g. the Azores and Cape Verde Islands (Santos, Porteiro \& Barreiros, 1997; Wirtz et al. 2013). The species is considered rare throughout its known range, but since its typical habitat (coralline and rocky offshore reefs) are seldom trawled, its population may be underestimated due to lack of capture records (Swaby \& Potts 1990; Pollard 2010). Little is known about its ecology; it is considered to live solitarily or in small groups, and the diet mainly consists of benthic invertebrates (Pollard 2010). It is light brown in colour and characterized by one black blotch on the posterior part of the dorsal fin, a black blotch on the dorsal part of the trunk and several lighter blotches on the back, below the dorsal fin. By these characteristics, the species is well distinguished from other wrasse species in Swedish waters. In the Mediterranean Sea it is often found on rocky bottoms at depths below $80 \mathrm{~m}$ (Sartoretto et al. 1997). In the northern parts 
72 of its range, however, it has been noted at shallower depth (from 18 m; Debelius, 1997; Kullander

73 et al., 2012).

74 In Norway, the species has been considered rare, albeit potentially yearly in occurrence (Curry-

75 Lindahl 1985), but recent evidence suggest that there are larger concentrations of the species in

76 e.g. the Hardangerfjord, and anecdotal reports from scuba-divers suggest it is more common than

77 previously thought (Espeland et al., 2010). The species is regularly captured by anglers in the

78 Norwegian part of northern Skagerrak, just south of Langesund, on rocky bottoms at 40 to $60 \mathrm{~m}$

79 depth, elevating from deeper soft bottoms (Fig. 1., position 1; M. Lundgren, personal observations;

80 also documented in the catch-records of the Langesund Seafood and Fishing Festival;

81 http://www.Isff.no/; data accessed 2014-04-23). The first recorded Scandinavian specimen

82 (recorded as A. Couchi) was retrieved in 1869 from around 50 meters depth in the area around the

83 island Hidra (Hitterø) close to Flekkefjord in south-western Norway, and is preserved at the

84 Swedish Museum of Natural History (cat. no. NRM 47556) (Öberg 1870; SMNH 2018; description

85 reiterated in Stuxberg 1894). This specimen was confirmed as an adult individual belonging to the

86 species Labrus palloni (junior synonym to $A$. palloni) by Lilljeborg (1881). Another three

87 preserved specimens from the Norwegian parts of the eastern Skagerrak (captured in 1966, 1968

88 and 1985), around the southern parts of the Oslofjord area (Fig. 1., one specimen at position 2, and

89

90

91

92

93

94 two specimens at position 3), are available at the Natural History Museum, University of Oslo, according to the Global Biodiversity Information Facility (GBIF) database (https://www.gbif.org/). In addition, Andersson (1964) notes that a few specimens had been caught between Stavanger and Kristiansand in Norway.

While the presence of $A$. palloni along the southern Norwegian coast is clearly documented with sporadic, but repeated, records over the last century, the eastern limits in the Skagerrak are not 
95 well established. The species has been noted as not being native to Swedish waters (Pethon \&

96 Svedberg, 2004; Nielsen \& Svedberg 2006; Pollard, 2010; Craig \& Pollard 2015), or alternatively,

97 only being present in the Koster Fjord area (Nilsson, 1997; Fig. 1, position 4). Whereas FishBase

98 (http://www.fishbase.org/; Froese \& Pauly 2018) lists the species as native, based on the Swedish

99 checklist of fishes (Kullander 1999); this checklist, however, lists all species recorded in Swedish

100 waters, including sporadic visitors. In an updated checklist, the occurrence of $A$. palloni is noted 101 as "sporadic" (Kullander 2002). The FishBase-associated AquaMaps project 102 (http://www.aquamaps.org/; Kaschner et al., 2016) has a predicted occurrence probability of 0.601030.79 in Swedish waters (Kesner-Reyes et al., 2016), based on a single verified and a few unverified 104 records in GBIF (the single verified record, from southern Skagerrak, is noted here in the Results 105 section). Recently, the distribution of the species has been suggested to be wider than previously 106 thought in Swedish waters, based on multiple reports of angled specimens. 
107

108

109

110

111

112

113

114

115

116

117

118

119

120

121

122

123

124

125

126

127

\section{MATERIALS AND METHODS}

Swedish non-angling records (1993-2016)

Non-angling records were sourced from the scientific literature (Cedhagen \& Hansson 1995;

Hallberg 2011), the Swedish Species Observation System (SSOS; http://www.artportalen.se/), and the GBIF-Sweden Data Portal (http://www.gbif.se/).

Swedish angling records (1995-2016)

The majority of the angling records were obtained from the curated specimen registry (Storfiskregistret) of the Swedish Anglers Association (SAA; http://www.sportfiskarna.se/), where anglers can report catches of fish specimens above a certain species-specific mass-limit, which then gets validated based on photographs, accessory information, and, if needed, expert assessment. The SAA records contains additional information about capture location, depth, habitat, and capture method. The mass-limit for recording an A. palloni in the SAA specimen registry is $250 \mathrm{~g}$ (effective since 2012; before that it was $300 \mathrm{~g}$, but no registered records exist from this time-period).

Additional records, were supplied by Swedish anglers, located through posts on internet blogs or through personal communication. A number of records are also direct personal observations by the authors (e.g. specimens in Figure 2). Furthermore, some records in the SAA registry had limited capture information. In such cases, the angler was contacted.

All records from the SAA database in Table 1 have been verified by the authors from photographs. SAA carries digital copies of all fish in their records. Personal communications were obtained from experienced sea anglers; some of these records are unverified (see Table 1) and should 
128 therefore be used mainly as auxiliary information. While misidentification of the species is 129 possible, specimen sea anglers are typically examining their catch closely when resembling a rare 130 species. Hence, the unverified angling records are judged to be valid. 
132

133

134

135

136

137

138

139

140

141

142

143

144

145

146

147

148

149

150

151

152

153

\section{RESULTS}

\section{Swedish non-angling records}

The occurrence of $A$. palloni in Swedish waters was rarely reported prior to 2010, with a first record of a juvenile specimen from year 1993 from somewhere between 50 and $115 \mathrm{~m}$ depth in the mouth of the Singlefjord, northeastern Skagerrak (Cedhagen \& Hansson, 1995; Fig. 1., position 5). The species has also been previously reported from the Koster Fjord area around the Koster Islands, northeastern Skagerrak, (Fig. 1, position 4; Hallberg, 2011) and 6 km west of Rörö Island (Fig 1., position 6), southern Skagerrak in 2008 (data provided by Swedish Museum of Natural History, Stockholm; accessed through GBIF-Sweden Data Portal, 2014-04-25; also reported as capture site by Palmkvist et al., 2016). Only two unverified observations were found in SSOS (as of 2018-05-22). The first record comes from Persgrunden (Fig. 1, position 7), stemming from a scientific transect investigation using a remotely operated vehicle in 2007; the second is a questionable record from the harbor of Käringön. The latter record (record 54966014 in SSOS) is not reported in Table 1, due to A. palloni not being a typical species seen in the shallow harbor waters [in contrast to the similar looking goldsinny wrasse Ctenolabrus rupestris (L.)].

\section{Angling records}

Between the first Swedish record in 1993 (Cedhagen \& Hansson 1995) and 2011, a few angling records of A. palloni were noted from different sites on the Swedish west coast (Table 1). Between 2011 and 2016, several records of $A$. palloni have been provided by leisure anglers (Table 1). Repeated captures of the species have been made across years, at least at a few positions (e.g. position 9; Table 1). 
154 Most angled specimens are reported to be caught on, or directly above, rocky bottom at depths of $155 \quad 28-50 \mathrm{~m}$. Another specimen standing out from the rest is record \#16 which is the only one caught 156 inshore (in the Gullmarn Fjord, Fig 1, Position 11), apart from the first Swedish record by 157 Cedhagen \& Hansson (1995). 
159

160

161

162

163

164

165

166

167

168

169

170

171

172

173

\section{DISCUSSION}

The presented records extend the knowledge about the marine ichthyofauna of eastern Skagerrak, which is a generally well documented area regarding fish species distributions (Kullander et al., 2012). In the light of the present summary of these records, we show that angling databases can be utilized as a source for information about the distribution of fish species which are seldom targeted by commercial fisheries, but specifically targeted by anglers.

\section{Acantholabrus palloni belongs to the Swedish ichthyofauna}

The angling records of $A$. palloni show that several individuals of this species being repeatedly caught in the same general locations, at multiple sites, in Swedish waters. It should be noted that number of angled specimens at any given position are likely related to the specific fishing pressure at that site, and data are limited to adult specimens as a consequence of the size-restrictions in the SSA database (see Materials and Methods). Still, these repeated captures across several years indicate that $A$. palloni could be currently established in, at least some, areas of eastern Skagerrak. Notably, the sites at which the species is recorded, matches the 40-80 m depth curve in Skagerrak, as well as the currents from the North Sea which bring higher-salinity water into the southern Skagerrak and northwards along the Swedish coast (Svansson, 1975; Fig. 1). It is worth noting that the current list of records (Table 1) is not a complete record of angled A. palloni, as several other specimens (typically smaller ones) have been verbally described to the authors by anglers, without any specific information being noted by the angler.

\section{Spatial and temporal distribution of the population}

The typical capture site for $A$. palloni is rocky reefs located largely within the general $40-80-\mathrm{m}$ depth range along the Swedish Skagerrak coast. Capture sites are also matching the route of the 
main currents bringing water from the North Sea. The bottom layer of the deeper parts of Skagerrak have a salinity similar to the North Sea and is substantially more saline than the water originating from the Baltic Sea in the upper layers and in Kattegatt to the south of Skagerrak (Svansson 1975). This likely makes the conditions in these areas suitable for marine species with a main distribution area in more saline waters, such as A. palloni.

The presence of the species at the offshore islands of the Atlantic (the Azores, Canary Islands, Madeira and Cape Verde) suggests that there is capacity for dispersal in the species. However, the temporal aspect of dispersal appears largely unknown. The angled specimens are all captured between May and October, which represents the time when the angling activity is highest. Given paucity of data from the winter-months, we cannot exclude that the species is a seasonally migratory species in this geographic area. An additional unverified underwater observation was made in November during a scientific expedition at Persgrunden (record \#4; Table 1); but November-temperatures at $>25 \mathrm{~m}$ depth largely matches spring- to early-summer temperatures (Svansson, 1975), so such an observation does not indicate a non-migratory behaviour. However, given the apparent strong reef-association, the small body size, and the labriform swimming mode, which is relatively inefficient for long-distance swimming (Sfakiotakis, Davies \& Lane, 1999), a seasonal migratory life-style seems unlikely. Notably, Craig and Pollard (2015) states that it is not a migratory species; however, without explicit support from data or references.

\section{Stability of the population}

The first Swedish record was a juvenile individual (Cedhagen \& Hansson, 1995), which is indicative, but not proof, of spawning in the area. It could be possible that Skagerrak acts as a sink for the A. palloni population, with fry or young individuals drifting into the Skagerrak area from 
203 the North Sea and then settling on suitable rocky reefs. Until spawning and viable fry can be 204 demonstrated from Skagerrak, it is not possible to know whether the Skagerrak population is self205 reproducing. Systematic investigations of angled specimens (e.g. in association with marine 206 angling competitions) could provide information about spawning activity, as well as other aspects 207 of their biology, such as feeding habits and parasite fauna - all of which are largely unknown for 208 209 210

the species (Kullander et al., 2012). Studies on population genetics may provide further insights into the population structure of the species (see e.g. Faust et al., 2018). Hence, such investigations could be encouraged to extend the knowledge of this data-deficient species.

\section{Range extension due to climate change?}

The recent surge in records could be an indication of a range extension. One hypothetical factor that could lead to range extensions is the changing climate which leads to higher seawater temperatures (Dye et al., 2013). While increased sea water temperature was also noted from 1939 to 1960 , the warming effect has been particularly strong in the north-east Atlantic during the last decades (Dye et al. 2013). The estimated temperature increase in Skagerrak, from 1990 to 2014, is $1.6^{\circ} \mathrm{C}$ (Rinde, Hjermann \& Staalstrøm, 2016). Range extensions has indeed been indicated in several European marine areas, including Scandinavian waters (Hiddink and ter Hofstede, 2008; Nicolas et al., 2011; Brattegard, 2011). Brattegard (2011) estimated that more than 500 marine benthic species expanded their range northwards in Norwegian waters, in the range of 750-1000 $\mathrm{km}$, between 1997 and 2010. Furthermore, several new species were found to establish along the Norwegian Skagerrak coast during this time (Brattegard, 2011; Rinde et al., 2016). Even though the angling records are located south of the previous northern range limit, the eastern Skagerrak is still at the edge of the species' northern distribution range (AquaMaps presents an estimated native distribution map that extends to the Faroe Islands, but this is not supported by actual records of the 
226 species [Kaschner et al., 2016; Kesner-Reyes et al., 2016)]. Hence, a climate-related population

227 increase at the northern distribution range may cause spillover effects into the Swedish waters of

228 Skagerrak, following the main currents in this area (cf. Fig. 1 and Rinde et al., 2016). However, 229 the paucity of historical data on the species makes it impossible to conclude whether this is the 230 case or not. The fact that the species was recorded in south-western Norway already in 1869 231 (Öberg, 1870), with further observations along the south coast of Norway noted prior to 1942 232 (Andersson, 1942), suggests that it was present, at least temporarily, close to Swedish waters prior to the recent increase in the seawater temperature. It is also very hard to distinguish climate effects from other effects such as fishing or meta-population dynamics (Brander and Havenhand, 2016).

Prior records missing due to historical angling methods and oversight?

Acantholabrus palloni is generally captured over off-shore rocky reefs. Smaller-sized marine fish species, such as A. palloni, have historically not been targeted by off-shore anglers to the same extent they currently are (Lundgren \& Waje, 2015). While coastal anglers use a wide variety of hook-sizes, off-shore anglers have, until recently, mainly used larger hooks targeting larger species. With the relatively small gape-size of $A$. palloni, this may effectively have eliminated the species from being caught, even though the capture sites reported here have been commonly targeted reefs for angling (Lundgren \& Waje, 2015). In addition, the typical rocky reef habitat is likely seldom trawled by commercial fishermen, probably leading to few specimens being caught in fisheries overall (Pollard, 2010). While clearly distinguished at closer inspection (which is typically what specimen sea anglers do), it also resembles the common goldsinny wrasse and young female cuckoo wrasse Labrus mixtus L. in coloration, which may lead to misidentification and oversight by e.g. fishermen not interested in the species for commercial purposes. These facts may have limited the number of captures and historical reports from Swedish waters. Similar 
249 oversight might apply to other rare Scandinavian species, such as Thorogobius ephippiatus (Lowe, 250 1839) and Pomatoschistus norvegicus (Collett, 1903) (Holm \& Mattson, 1980; Cedhagen \& 251 Hansson, 1995).

\section{Value for Swedish fisheries}

Despite its relatively small size, $A$. palloni has value for marine specimen angling, e.g. in marine angling competitions where the number of species caught is rewarded. In fact, the angling records being presented in this article are largely a consequence of this species being acknowledged as a target for specimen anglers, who are specifically targeting large specimens of different species (e.g. Hellenberg, 2014a,b; Lundgren \& Waje, 2015). In commercial fisheries, however, it has generally little or no value (Machias et al., 2001; Nielsen \& Svedberg 2006), although it has been noted among the targeted species in some Mediterranean countries (e.g. Alegre, Lleonart \& Veny, 1992; Economidis \& Koutrakis, 2001). Smaller wrasse species are fished commercially in Scandinavia for sea lice control in salmon farms (Espeland et al., 2010), but $A$. palloni is not suited for such fishery as it is deeper-living than most of the other smaller wrasses [e.g. corkwing wrasse Symphodus melops (L.) and juvenile ballan wrasse Labrus bergylta Ascanius, 1767] and, thus, generally subjected to severe barotrauma when hauled, resulting in inflated swim-bladders and bulging eye-balls (see e.g. Fig. 2).

Using angling records for conservation and management of rare fishes

This study presents a case where citizen generated data can be used for increasing the knowledge about a rare species. It is possible that recognition of the angler community as a valuable source of information may increase anglers' interest in continuing and increasing the frequency and detail of their reports. Anglers are often keen to participate in the management of fish stocks, but may 
271 also be skeptical about revealing the exact location of their fishing sites, so this type of recognition 272 may lead to a further increased interest in fish conservation issues (Granek et al., 2008; Fetterplace 273 et al. 2018). From a conservation and management perspective, the current data provides a 274 tentative picture of the distribution and habitat in Swedish waters. A quantitative habitat suitability 275 model (HSM) is, however, not possible to construct, mainly due to the scarcity of data about habitat 276 conditions at capture sites. Bradter et al. (2018) constructed HSMs for Siberian Jays in Sweden, 277 utilizing data from the SSOS. As compared to e.g. birds, for which the SSOS reporting system is 278 run in collaboration with BirdLife Sweden (the Swedish Ornithological Society), fish appear to be 279 under-reported in SSOS. Hence, the SAA database appears to be substantially more informative 280 and reliable for observational reports of fish at the present point in time, despite having a lower 281 mass-limits for reports, which limits the number of reports in general and completely eliminates 282 reports of juvenile specimens. 
284

285

286

287 288

289

290

291

292

293

294

295

296

297

298

299

300

301

\section{CONCLUSIONS}

In this article, we summarize the present knowledge about the current distribution of $A$. palloni in Swedish waters, at the edge of the distribution range of the species. The records of $A$. palloni presented here in particular highlight the importance of citizen-generated data in the form of anglers' reports and angling records as useful contributions for ichthyological investigations of presence and distribution of non-commercial fish species.

\section{ACKNOWLEDGEMENTS}

We thank Magnus Durell, Mattias Jonsson, Mattias Liewendahl, Arvid Enemar and Dan Calderon for providing details on their catches of scale-rayed wrasse. Nicka Hellenberg is thanked for curating the Storfiskregistret specimen database. Three anonymous reviewers are thanked for contributing valuable comments and information.

\section{ETHICAL APPROVAL}

This article does not contain any direct studies with animals performed by any of the authors.

\section{SAMPLING AND FIELD STUDIES}

Fish specimens reported were caught following Swedish or Norwegian angling regulations. All cases where the authors captured recorded specimens were part of non-scientific angling expeditions, conducted prior to the conception of the study. 


\section{REFERENCES}

Able KW. 2016. Natural history: an approach whose time has come, passed, and needs to be resurrected. ICES Journal of Marine Science 73: 2150-2155.

Alegre M, Lleonart J, Veny J. 1992. Espècies pesqueres d'interès commercial: nomenclatura official catalana. Barcelona: Departament de Cultura, Generalitat de Catalunya. (In Catalan)

Andersson KA. 1942. Fiskar och fiske i Norden. Bd. 1, Fiskar och fiske i havet. Stockholm: Natur och Kultur. (In Swedish)

Anonymous. 2017a. Brunsnultra från Måseskär. Svenskt Fiske 1:2017: 60. (In Swedish)

Anonymous. 2017a. Sportfiskeåret 2016: Saltvattensfiskar. Svenskt Fiske 1:2017: 74. (In Swedish)

Arlinghaus R, Tillner R, Bork M. 2015. Explaining participation rates in recreational fishing across industrialised countries. Fisheries Management and Ecology 22: 45-55.

Banha F, Iléhu M, Anastácio PM. 2015. Angling web forums as an additional tool for detection of new fish introductions: the first record of Perca fluviatilis in continental Portugal. Knowledge and Management of Aquatic Ecosystems 416: 03.

Boero F. 2013. Observational articles: a tool to reconstruct ecological history based on chronicling unusual events. F1000Research 2: 168.

Bradter U, Mair L, Jönsson M, Knape J, Singer A, Snäll T. 2018. Can opportunistically collected Citizen Science data fill a data gap for suitability models of less common species? Methods in Ecology and Evolution: in press. DOI: 10.1111/2041-21X.13012 
322 Brander K., Havenhand J. 2016. Impacts of climate change, including acidification, on marine

323

324

325

326

327 ecosystems and fisheries. In Reckermann M, Brander K, MacKenzie BR, Omstedt A. (eds.) Climate Impacts on the Baltic Sea: From Science to Policy. Berlin Heidelberg: SpringerVerlag, pp. 129-160.

Brattegard T. 2001. Endringer i norsk marin bunnfauna 1997-2011. DN-utredning 8-2011. Trondheim: Direktoratet for Naturforvaltning. (In Norwegian).

Cedhagen T, Hansson HG. 1995. First records of Acantholabrus palloni (Risso, 1810) (Labridae) and Pomatoschistus norvegicus (Collett, 1903) (Gobiidae) in the Swedish fish fauna, and a note on the distribution of Cottunculus microps Collett, 1875 (Psychrolutidae). Sarsia 80: $33-34$

Craig MT, Pollard D. 2015. Acantholabrus palloni. The IUCN Red List of Threatened Species 2015: e.T186106A44906675. http://www.iucnredlist.org/, accessed on 12 May 2018.

Curry-Lindahl K. 1985. Våra fiskar - havs- och sötvattensfiskar i Norden och övriga Europa. Stockholm: P.A. Norstedts \& Söners Förlag. (In Swedish)

Debelius H. 1997. Mediterranean and Atlantic fish guide. Frankfurt: IKAN - Unterwasserarchiv, $305 \mathrm{pp}$.

Devictor V, Whittaker RJ, Beltrame C. 2010. Beyond scarcity: citizen science programmes as useful tools for conservation biogeography. Diversity and Distributions 16: 354-362. 
Dye SR, Hughes SL, Tinker J, Berry DI, Holliday NP, Kent EC, Kennington K, Inall M, Smyth T, Nolan G, Lyons K, Andres O, Beszczynska-Möller A. 2013. Impacts of climate change on temperature (air and sea). MCCIP Science Review 2013: 1-12.

Economidis PS, Koutrakis E. 2001. Common names of commercially important Hellenic marine organisms. Thessaloniki: Aristotle University.

Espeland SH, Nedreaas K, Mortensen S, Skiftesvik AB, Agnalt A-L, Durif C, Harkestad LS, Karlsbakk E, Knutsen H, Thangstad T, Jørstad K, Bjordal Å, Gjøsæter J. 2010. Kunnskapsstatus leppefisk - utfordringer i et økende fiskeri. Fisken og Havet 7/2010, Institute of Marine Research, 35 pp. (In Norwegian)

Faust E, Halvorsen KT, Andersen P, Knutsen H, André C. 2018. Cleaner fish escape salmon farms and hybridize with local wrasse populations. Royal Society Open Science 5: 171752.

Fetterplace LC, Turnbull JW, Knott NA, Hardy NA. 2018. The devil in the deep: expanding the known habitat of a rare and protected fish. European Journal of Ecology 4: 22-29.

Froese R, Pauly D. 2018. FishBase. World Wide Web electronic publication. http://www.fishbase.org/, version 02/2018

Granek EF, Madin EMP, Brown MA, Figueira W, Cameron DS, Hogan Z, Kristianson G, de Villiers P, Williams JE, Post J, Zahn S, Arlinghaus R. 2008. Engaging recreational fishers in management and conservation: global case studies. Conservation Biology 22: 1125-1134.

Hallberg E. 2011. Assemblages of mobile fauna in the Koster-area: correlative patterns, predictive modelling, mapping and possible applications in the planning of a marine national park. 
MSc thesis, University of Gothenburg, Sweden, 33 pp.

361

362

363

364

365

366

367

368

369

370

371

372

373

374

375

Hanefors B. 1995. Brunsnultra - en ovanlig fångst. Sportfiske 12:1995: 73. (In Swedish)

Hellenberg N. 2014a. Brunsnultra - en ny art och nytt rekord. Svenskt Fiske 4:2014: 65. (In Swedish)

Hellenberg N. 2014b. Nytt rekord under rekordåret. Svenskt Fiske 5:2014: 64. (In Swedish)

Hiddink JG, ter Hofstede R. 2008. Climate induced increases in species richness of marine fishes. Global Change Biology 14: 453-460.

Holm T, Mattson S. 1980. Thorogobius ephippiatus (Pisces) found on the west coast of Sweden. Sarsia 66: 87-88.

Hyder K, Weltersbach MS, Armstrong M, Ferter K, Townhill B, Ahvonen A, Arlinghaus R, Baikov A, Bellanger M, Birzaks J, Borch T, Cambie G, de Graaf M, Diogo HMC, Dziemian Ł, Gordoa A, Grzebielec R, Hartill B, Kagervall A, Kapiris K, Karlsson M, Klieven AR, Lejk AM, Levrel H, Lovell S, Lyle J, Moilanen P, Monkman G, Morales-Nin B, Mugerza E, Martinez R, O’Reilly P, Olesen HJ, Papadopoulos A, Pita P, Radford Z, Radtke K, Roche W, Rocklin D, Ruiz J, Scougal C, Silvestri R, Skov C, Steinback S, Sundelöf A, Svagzdys A, Turnbull D, van der Hammen T, van Voorhees D, van Winsen F, Verleye T, Veiga P, Vølstad J-H, Zarauz L, Zolubas T, Strehlow HV. 2018. Recreational sea fishing in Europe in a global context - participation rates, fishing effort, expenditure, and implications for monitoring and assessment. Fish and Fisheries 19: 225-243. 
379 Kaschner K, Kesner-Reyes K, Garilao C, Rius-Barile J, Rees T, Froese R. 2016. AquaMaps: 380 Predicted range maps for aquatic species. World Wide Web electronic publication, www.aquamaps.org, Version 08/2016.

382

383

384

385

386

387

388

389

390

391

392

393

394

395

396

397

Kesner-Reyes K, Kaschner K, Kullander S, Garilao C, Barile J, Froese R. 2016. AquaMaps: algorithm and data sources for aquatic organisms. In: Froese R \& Pauly D (eds). 2016. FishBase. World Wide Web electronic publication. http://www.fishbase.org/, version $04 / 2012$

Kullander SO. 1999. Swedish fishes: checklist of Swedish fishes. Stockholm: Swedish Museum of Natural History.

Kullander SO. 2002. Svenska fiskar: förteckning över svenska fiskar. World Wide Web electronic publication. Stockholm: Swedish Museum of Natural History. (in Swedish) http://www2.nrm.se/ve/pisces/allfish.shtml.se

Kullander SO, Nyman L, Jilg K, Delling B. 2012. Nationalnyckeln till Sveriges flora och fauna. Strålfeniga fiskar. Actinopterygii. Uppsala: ArtDatabanken, 517 pp. (In Swedish)

Larsson O, Stevens RL. 2008. Seismic stratigraphy of Late Quaternary deposits in the eastern Skagerrak. Marine and Petroleum Geology 25: 1023-1039.

Lilljeborg W. 1881. Labrus palloni (Risso). Pallonsnultran. In: Lilljeborg W. 1881. Sveriges och Norges fiskar. Upsala: W. Schultz, pp. 447-452. (In Swedish)

Lundgren M, Waje L. 2015. Havsfiskeboken. Vallda: Twow! (In Swedish) 
398 Machias A, Vassilopoulou V, Vatsos D, Kallianiotis A, Papaconstantinou C, Tsimenides N. 2001.

399

400

401

402

403

404

405

406

407

408

409

410

411

412

413

414

415

416
Bottom trawl discards in the northeastern Mediterranean Sea. Fisheries Research 53: 181195.

Muus BJ, Nielsen JG, Svedberg U. 1999. Havsfisk och fiske i Nordvästeuropa. Stockholm: Bokförlaget Prisma, 337 pp. (In Swedish)

Nicolas D, Chaalali A, Drouineau H, Lobry J, Borja A, Boët P. (2011). Impact of global warming on European tidal estuaries: some evidence of northward migration of estuarine fish species. Regional Environmental Change 11: 639-649.

Nielsen L, Svedberg U. 2006. Våra fiskar. Stockholm: Prisma. (In0 Swedish)

Nilsson P. 1997. Biologiska värden i Kosterfjorden - en sammanställning och analys av nuvarande kunskap. Naturvårdsverket Rapport 4749, Naturvårdsverket (Swedish Environmental Protection Agency), 75 pp. (In Swedish)

Palmkvist J, Scherer A, Liungman A, Rådén R, Mattson M. 2016. Rapport nummer 1: Epibentisk fauna i Västerhavet. In: Länsstyrelserna Västra Götaland, Halland och Skåne län. 2016. Inventering av marin epibentisk fauna på djupa bottnar, online publication: Länsstyrelserna Västra Götaland, Halland och Skåne län, pp. 7-142. Available at: www.lansstyrelsen.se/vastragotaland (report 2016:30) (In Swedish)

Pethon P, Svedberg U. 2004. Fiskar, $4^{\text {th }}$ edition. Stockholm: Bokförlaget Prisma, 245 pp. (In Swedish) 
417 Pollard D. 2010. Acantholabrus palloni. The IUCN Red List of Threatened Species 2010: e.T186106A8501267. http://www.iucnredlist.org/, accessed on 12 May 2018.

Rinde E, Hjermann DØ, Staalstrøm A. 2016. Larvae drift simulation of the Pacific oyster in Skagerrak - influence of climate change on larvae development, survival and dispersal. NIVA Report 7016-2016. Oslo: Norwegian Institute for Water Research.

Santos RS, Porteiro FM, Barreiros JP. 1997. Marine fishes of the Azores: annotated checklist and bibliography: a catalogue of the Azorean marine ichthyodiversity. Ponta Delgada: Universidade dos Açores.

Sartoretto S, Francour P, Harmelin,J-G, Charbonnel É. 1997. Observations in situ de deux Labridae profonds, Lapanella fasciata et Acantholabrus palloni, en Méditerranée nordoccidentale. Cybium 21: 37-44. (In French)

Sfakiotakis M, Davies JBC, Lane DM. 1999. Review of fish swimming modes for aquatic locomotion. IEEE Journal of Oceanic Engineering 24: 237-252.

Silvertown J. 2009. A new dawn for citizen science. Trends in Ecology \& Evolution 24: 467-471.

Skov C, Jansen T, Arlinghaus R. 2017. 62 years of population dynamics of European perch (Perca fluviatilis) in a mesotrophic lake tracked using angler diaries: the role of commercial fishing, predation and temperature. Fisheries Research 195: 71-79.

SMNH (Swedish Museum of Natural History). 2018. Ichthyology Database: Collection report 47556. Available at: http://artedi.nrm.se/nrmfish/ (retieved: 2018-08-17). 
436 Stuxberg A. 1894. Sveriges och Norges fiskar. Deras lefnadssätt, födoämnen, lektid, förekomst 437 och utbredning jämte inledning till fiskarnes naturalhistoria. Göteborg: Wettergren \&

438

439

440

441

442

443

444

445

446

447

448

449

450 Kerber. (In Swedish)

Svansson A. 1975. Physical and chemical oceanography of the Skagerrak and the Kattegatt. I. Open sea conditions. Institute of Marine Research, Report No. 1. Uddevalla: Fishery Board of Sweden/Bohusläningens AB.

Swaby SE, Potts GW. 1990. Rare British marine fishes - identification and conservation. Journal of Fish Biology 37 (supplement A): 133-143.

Venturelli PA, Hyder K, Skov C. 2017. Angler apps as a source of recreational fisheries data: opportunities, challenges and proposed standards. Fish and Fisheries 18: 578-595.

Wirtz P, Brito A, Falcón JM, Freitas R, Fricke R, Monteiro V, Reiner F, Tariche O. 2013. The coastal fishes of the Cape Verde Islands - new records and an annotated check-list. Spixiana 36: 113-142.

Öberg PEW. 1870. Acantholabrus Couchi Cuv. Et Val., en för Skandinaviens fauna ny fiskart. Öfversigt af Kongl. Vetenskaps-Akademiens Förhandlingar 1870: 391-395. (In Swedish) 
451

452

453

454

455

456

457

458

459

460

461

462

463

464

465

466

467

468

469

FIGURE LEGENDS

Figure 1. Positions for records of Acantholabrus palloni in Skagerrak. Red dots represent nonangling records, showing the previously documented occurrence, and blue dots represent angling records reported in this paper. Red arrows show the large-scale current patterns in the area, and dotted lines delineate approximate 40- and 80-m depth curves. A: Hidra Island, Norway, first Scandinavian record (Öberg 1870); B: Singlefjord mouth, Sweden, first Swedish record (identical to position 5) (Cedhagen \& Hansson 1995); 1: S. Langesund city, Norway; 2: Ferder Lighthouse, Oslofjord, Norway; 3: S. Missingen Islands, Oslofjord, Norway; 4: Koster Fjord area, Sweden; 5: Singlefjord mouth, Sweden; 6: W. Stora Pölsan lighthouse, Sweden; 7: Persgrunden, Sweden; 8: Grisbådarna, Sweden; 9: Kullarna (S.W. Måseskär lighthouse), Sweden; 10: N.W. Hunnebostrand city, Sweden; 11: Gullmarn Fjord, Sweden; 12: Svaberget, Sweden; 13: Väderöarna (Weather Islands), Sweden; 14: W. Ursholmen Island. Names of areas of angling grounds (pos. 7-9, and 12) are based on Lundgren \& Waje (2015); currents and depth curves are drawn after Svansson (1975) and Larsson and Stevens (2008).

Figure 2. Pictures of Acantholabrus palloni from Swedish waters (Position 9 in Fig. 1). (A) Record \#8, Table 1; (B) Record \#9, Table 1. Published with permission (Photo credit: M. Lundgren). 


\section{Table $\mathbf{1}$ (on next page)}

Records of $A$. palloni in Swedish waters.

$\mathrm{L}=$ Total length, $\mathrm{M}=$ wet mass. 
1 Table 1. Records of $A$. palloni in Swedish waters. $\mathrm{L}=$ Total length, $\mathrm{M}=$ wet mass.

\begin{tabular}{|c|c|c|c|c|c|c|}
\hline $\begin{array}{l}\text { Record } \\
\text { number }\end{array}$ & Date & Size & $\begin{array}{l}\text { Capture } \\
\text { method }\end{array}$ & $\begin{array}{l}\text { Location (Fig } \\
\text { 1) }\end{array}$ & Notes & Information source \\
\hline 1 & 1993 & Juvenile & Dredge haul & Pos 5 & $\begin{array}{l}\text { First record from Swedish } \\
\text { waters, first inshore record }\end{array}$ & $\begin{array}{l}\text { Cedhagen \& Hansson } \\
1995\end{array}$ \\
\hline 2 & 1995-07 & $\begin{array}{l}\mathrm{L}: 23 \mathrm{~cm} \\
\mathrm{M}: 142 \mathrm{~g}\end{array}$ & Angling & Pos 8 & & Hanefors 1995 \\
\hline 3 & 2007-07-09 & $\begin{array}{l}\mathrm{L}: \text { No record } \\
\mathrm{M}: 265 \mathrm{~g}\end{array}$ & Angling & Pos 7 & Verified by M. Lundgren & $\begin{array}{l}\text { Records of Kungsbacka } \\
\text { Angling Club }\end{array}$ \\
\hline 4 & 2007-11-16 & $\begin{array}{l}\text { L: No record } \\
\text { M: No record }\end{array}$ & $\begin{array}{l}\text { Filmed, } \\
\text { Remotely } \\
\text { Operated } \\
\text { Vehicle }\end{array}$ & Pos 7 & $\begin{array}{l}50 \text { m depth. Reported by A. } \\
\text { Tullot (record \#61250199). } \\
\text { Unverified. }\end{array}$ & https://artportalen.se/ \\
\hline 5 & 2008 & $\begin{array}{l}\text { L: No record } \\
\text { M: No record }\end{array}$ & Unknown & Pos 6 & $\begin{array}{l}\text { Verified by S.O. Kullander, } \\
\text { Swedish Museum of Natural } \\
\text { History in GBIF }\end{array}$ & http://www.gbif.se/ \\
\hline 6 & $\begin{array}{l}\text { No info. } \\
\text { (Pre-2011) }\end{array}$ & $\begin{array}{l}\text { L: No record } \\
\text { M: No record }\end{array}$ & $\begin{array}{l}\text { Filmed, } \\
\text { Remotely } \\
\text { Operated } \\
\text { Vehicle }\end{array}$ & Pos 4 & & Hallberg 2011 \\
\hline 7 & 2010 & $\begin{array}{l}\text { L: No record } \\
\text { M: No record }\end{array}$ & Angling & Pos 9 & $\begin{array}{l}\text { Verified by } \mathrm{M} \text {. Lundgren, } \\
\text { direct observation }\end{array}$ & M. Durell, pers. comm. \\
\hline 8 & 2011-06-04 & $\begin{array}{l}\text { L: No record } \\
\text { M: } 220 \mathrm{~g}\end{array}$ & Angling & Pos 9 & Figure 2. & M. Lundgren, pers. obs. \\
\hline 9 & 2011-06-05 & $\begin{array}{l}\mathrm{L}: \text { No record } \\
\mathrm{M}: 180 \mathrm{~g}\end{array}$ & Angling & Pos 9 & Figure 2. & M. Lundgren, pers. obs. \\
\hline
\end{tabular}


10

11

\section{1-06-05}

L: No record M: $160-180 \mathrm{~g}$ (estimated)

2012-05-26 L: No record M: $120 \mathrm{~g}$

\section{4-06-01}

L: $26 \mathrm{~cm}$

M: $275 \mathrm{~g}$

2014-07-26

L: $26 \mathrm{~cm}$

M: $260 \mathrm{~g}$

$$
\text { 2014-08-16 }
$$

L: $26 \mathrm{~cm}$ M: $250 \mathrm{~g}$

2014-08-16

L: $27.5 \mathrm{~cm}$ M: $282 \mathrm{~g}$

2015-07-13

L: No record M: $200 \mathrm{~g}$

$\begin{array}{llll}2015-07-17 & \text { L: } 29 \mathrm{~cm} & \text { Angling } & \text { Pos } 12 \\ & \text { M: } 296 \mathrm{~g} & & \\ \text { 2015-08-06 } & \text { L: } 28 \mathrm{~cm} & \text { Angling } & \text { Pos } 10 \\ & \text { M: } 293 \mathrm{~g} & & \\ & & & \text { Pos } 10 \\ 2015-08-06 & \text { L: } 28 \mathrm{~cm} & \text { Angling } & \\ & \text { M: } 285 \mathrm{~g} & & \text { Pos } 10 \\ 2015-08-06 & \text { L: } 27 \mathrm{~cm} & \text { Angling } & \end{array}$

Pos 9

Pos 9

Pos 9

Pos 10

Pos 10

Pos 10

Pos 11

Angling

Angling

Angling

Angling

(n)


2015-08-09

L: $27.5 \mathrm{~cm} \quad$ Angling

M: $260 \mathrm{~g}$

2015-08-20

L: $26.5 \mathrm{~cm}$ M: $260 \mathrm{~g}$

Angling

L: $26 \mathrm{~cm}$ M: $250 \mathrm{~g}$

2015-08-21

L: $27 \mathrm{~cm}$ M: $260 \mathrm{~g}$

$$
\text { 2015-08-22 }
$$

L: $27 \mathrm{~cm}$ M: $280 \mathrm{~g}$

2015-08-22

L: $27.5 \mathrm{~cm}$

M: $267 \mathrm{~g}$

2015-08-22

L: $28 \mathrm{~cm}$

M: $270 \mathrm{~g}$

$$
\text { 2015-08-22 }
$$

L: $28.5 \mathrm{~cm}$ M: $300 \mathrm{~g}$

2015-08/09

L: No record
M: No record

Filmed,

2015-10-04 L: $27 \mathrm{~cm} \quad$ Angling M: $270 \mathrm{~g}$

2016-07-24

\begin{abstract}
L: $26 \mathrm{~cm}$ M: $260 \mathrm{~g}$
\end{abstract}

Remotely

Operated

Vehicle

Pos 13

Pos 9

Pos 9

Pos 13

Pos 10

Pos 10

Pos 10

Pos 10

Pos 6

Pos 6

Angling

Pos 8
$35 \mathrm{~m}$ depth, rocky bottom

$42 \mathrm{~m}$ depth, rocky bottom

$41 \mathrm{~m}$ depth, rocky bottom

$32 \mathrm{~m}$ depth, rocky bottom

$40 \mathrm{~m}$ depth

$38 \mathrm{~m}$ depth, rocky bottom

$40 \mathrm{~m}$ depth, rocky bottom

$45 \mathrm{~m}$ depth, rocky bottom

30-35 m depth, rocky bottom

$28 \mathrm{~m}$ depth, rocky bottom

$37 \mathrm{~m}$ depth, rocky bottom Verified from photograph by $\mathrm{J}$. Näslund http://www.sportfiskarna. $\underline{\mathrm{se} /}$

http://www.sportfiskarna. $\underline{\mathrm{se} /}$

http://www.sportfiskarna. $\underline{\mathrm{se} /}$

http://www.sportfiskarna. $\underline{\mathrm{se} /}$

http://www.sportfiskarna. se/

http://www.sportfiskarna. $\underline{\mathrm{se} /}$

http://www.sportfiskarna. se/

http://www.sportfiskarna. $\underline{\mathrm{se} /}$

Palmkvist et al. 2016

http://www.sportfiskarna.

A. Enemar, pers. comm. 


\begin{tabular}{|c|c|c|c|c|c|c|}
\hline $32-37$ & 2016-09 & $\begin{array}{l}\text { L: No record } \\
\text { M: } 70-200 \mathrm{~g}\end{array}$ & Angling & Pos 14 & $\begin{array}{l}5 \text { individuals. } 35-50 \mathrm{~m} \text { depth, } \\
\text { rocky bottom }\end{array}$ & A. Enemar, pers. comm. \\
\hline 38 & 2016-08-19 & $\begin{array}{l}\mathrm{L}: 28.5 \mathrm{~cm} \\
\mathrm{M}: 320 \mathrm{~g}\end{array}$ & Angling & Pos 9 & $42 \mathrm{~m}$ depth, rocky bottom & $\begin{array}{l}\underline{\mathrm{http}: / / \text { www.sportfiskarna. }} \\
\underline{\mathrm{se} /}\end{array}$ \\
\hline 39 & $2016-08-25$ & $\begin{array}{l}\mathrm{L}: 26.5 \mathrm{~cm} \\
\mathrm{M}: 270 \mathrm{~g}\end{array}$ & Angling & Pos 12 & $41 \mathrm{~m}$ depth, rocky bottom & 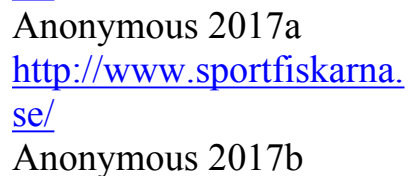 \\
\hline
\end{tabular}

1. Possibly an error in the report of depth 


\section{Figure 1}

Positions for records of Acantholabrus palloni in Skagerrak.

Red dots represent non-angling records, showing the previously documented occurrence, and blue dots represent angling records reported in this paper. Red arrows show the large-scale current patterns in the area, and dotted lines delineate approximate 40- and 80-m depth curves. A: Hidra Island, Norway, first Scandinavian record (Öberg 1870); B: Singlefjord mouth, Sweden, first Swedish record (identical to position 5) (Cedhagen \& Hansson 1995); 1: S. Langesund city, Norway; 2: Ferder Lighthouse, Oslofjord, Norway; 3: S. Missingen Islands, Oslofjord, Norway; 4: Koster Fjord area, Sweden; 5: Singlefjord mouth, Sweden; 6: W. Stora Pölsan lighthouse, Sweden; 7: Persgrunden, Sweden; 8: Grisbådarna, Sweden; 9: Kullarna (S.W. Måseskär lighthouse), Sweden; 10: N.W. Hunnebostrand city, Sweden; 11: Gullmarn Fjord, Sweden; 12: Svaberget, Sweden; 13: Väderöarna (Weather Islands), Sweden; 14: W. Ursholmen Island. Names of areas of angling grounds (pos. 7-9, and 12) are based on Lundgren \& Waje (2015); currents and depth curves are drawn after Svansson (1975) and Larsson and Stevens (2008). 

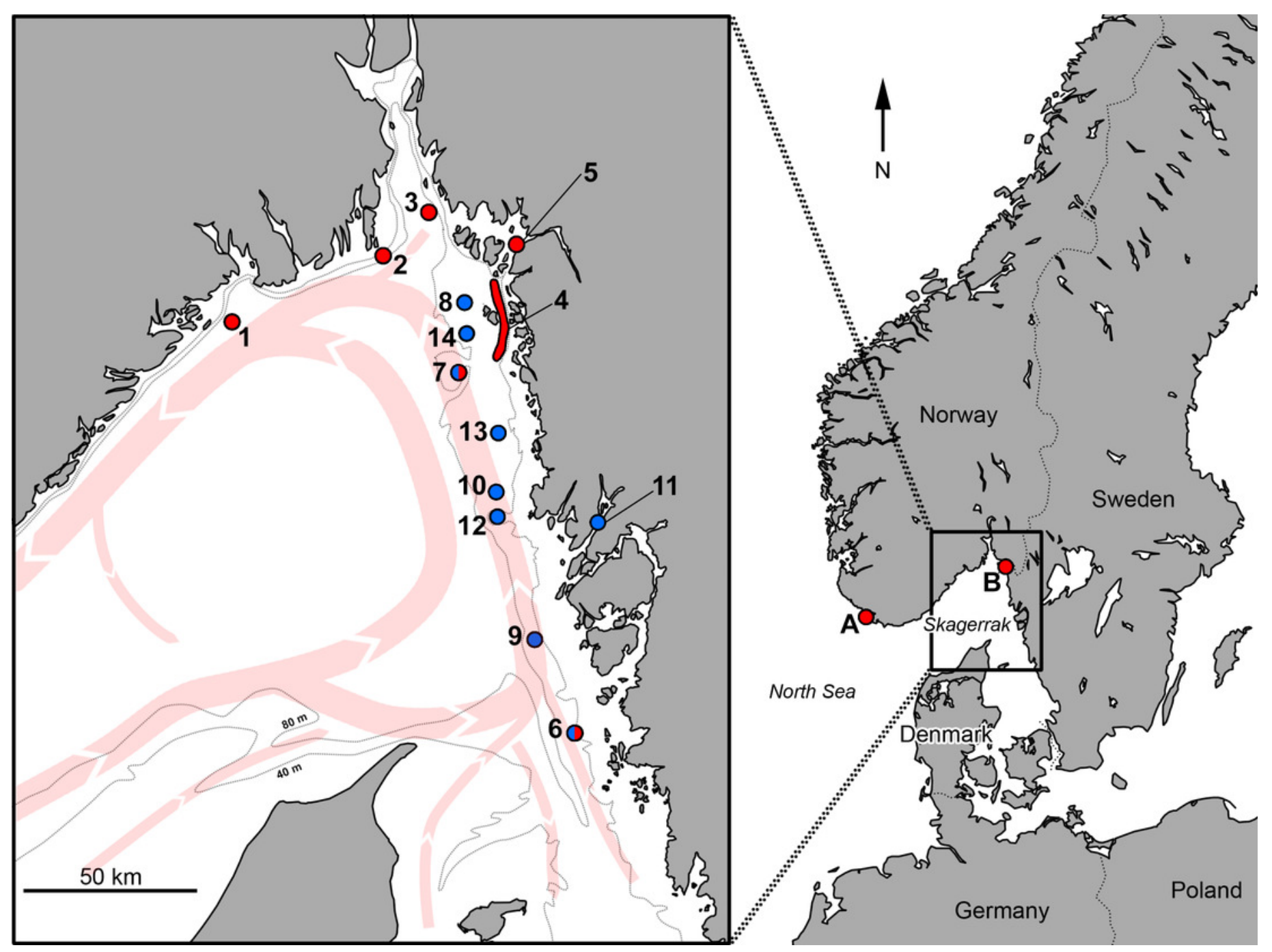


\section{Figure 2}

Pictures of Acantholabrus palloni from Swedish waters (Position 9 in Fig. 1).

(A) Record \#8, Table 1; (B) Record \#9, Table 1. Published with permission (Photo credit: M. Lundgren).
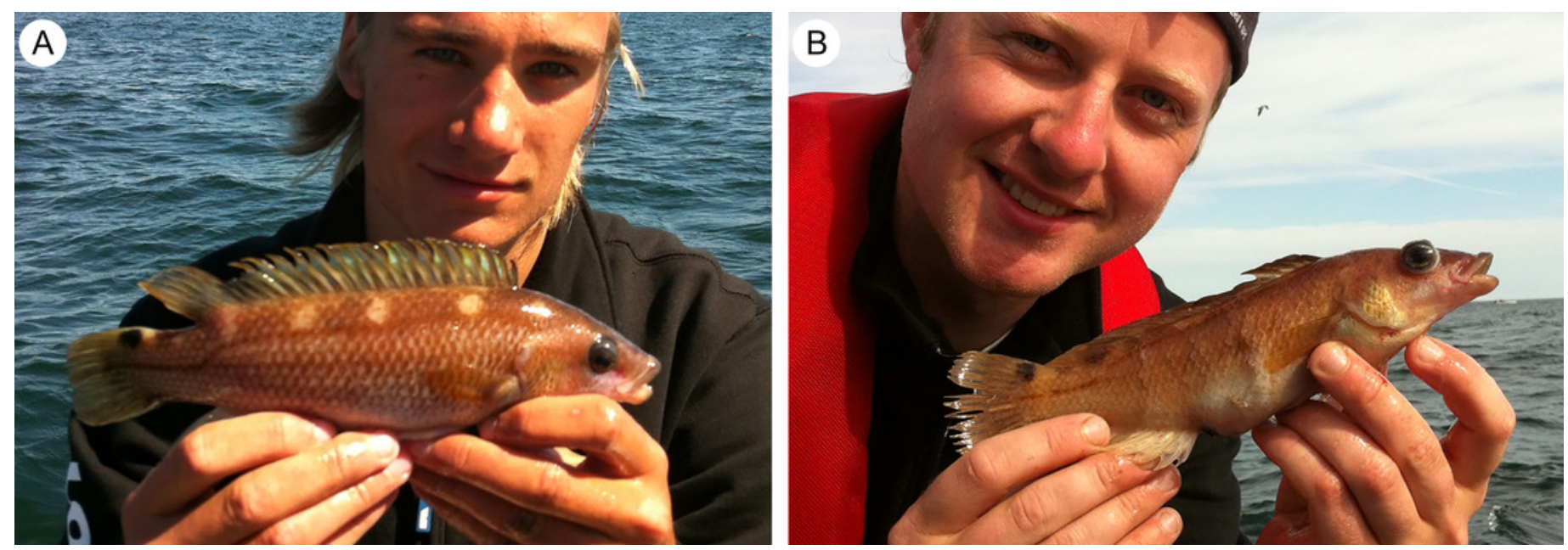